\title{
Fulminant Hepatic Failure: Clinical Spectrum \& Outcome
}

\author{
${ }^{1 *}$ Pranav Deore, ${ }^{2}$ Sayali Bhambar ${ }^{3}$ Smit Janrao, ${ }^{4}$ Rahul Rathod, \\ ${ }_{1,2,3,4}$ Resident, Department of Medicine, MVP's Dr. Vasantrao Pawar Medical College, \\ Hospital and Research Centre Adgaon, Nashik
}

\begin{abstract}
:
Introduction: Present study was conducted to assess the demographic characteristics, risk factors, causative spectrum, clinical features, natural course and outcome in patients of fulminant hepatic failure. We also tried to study the outcome in relation to risk factors, etiology, clinical and biochemical parameters and derive prognostic indicators that would be relevant to fulminant hepatic failure patients.

Materials \& Methods: A total of 36 diagnosed cases of Fulminant hepatic failure, fulfilling our inclusion and exclusion criteria were selected for the study. The detailed clinical history, complete general, systemic examination, central nervous system examination and investigation findings was noted in a predesigned proforma. The baseline functional status (motor, sensory, autonomous) was assessed and severity of disease was classified using Modified Parsons-Smith scale of hepatic encephalopathy Classification. Patient's progress was observed on the basis of parameters in classification and addition laboratory investigations. Patients was followed till the time of discharge or death, if happens. During hospital stay, patients were monitored for occurrence of complications, if any. The outcome of fulminant hepatic failure was measured in terms of duration of recovery and discharge or death.

Results: Most of the patients were less than 30 years (52.8\%) slight female predominance (55.6\% vs $44.4 \%)$. Most common cause of fulminant hepatic failure was HEV (36.1\%) followed by HBV, Indeterminate Hepatitis, AKT induced, AFLP and Auto-immune Hepatitis. Most of the patients were in encepahalopathy grade III (52.8\%), followed by grade II (25\%). Out of the total 36 patients, 22 patients died (61.1\%), while 14 patients $(38.9 \%)$ survived. Most common cause of death was cerebral edema (72.7\%) while sepsis was the cause in $27.3 \%$ patients. Presence of sepsis, high total billirubin and cerebral oedema were significantly associated with poor outcome.

Conclusion: Most common cause of fulminant hepatic failure was HEV followed by HBV. The mortality rate with fulminant hepatic failure was high at $61.1 \%$ with most common causes being cerebral oedema and sepsis. Presence of cerebral oedema and high total bilirubin levels were significantly associated with poor outcome.

Keywords: Clinical Spectrum, Fulminant Hepatic Failure, Mortality, Sepsis, Viral Hepatitis
\end{abstract}

\section{Introduction}

Fulminant hepatic failure (FHF) of Fulminant Hepatitis (FH) is defined by the sudden onset of hepatic encephalopathy in an otherwise healthy individual, often in association with coagulopathy, jaundice and multisystem organ failure. It is one of the most challenging gastrointestinal emergencies encountered in clinical practice and encompasses a pattern of clinical symptoms and pathophysiological responses associated with the rapid arrest of normal hepatic function [1].

The main causes of FH are viral infections, drugs, and indeterminate causes. Early elucidation of the cause of acute liver failure (ALF) is one reason to refer patients to a specialist center as quickly as possible so that its consequences can be established promptly and the appropriate treatment can be initiated.

At present there are no universally accepted criteria for the diagnosis of Fulminant hepatic failure. It carries high mortality rate with short-term transplant-free survival rate of $43 \%$ [2]. Moreover, it accounts for about $7 \%$ of liver transplants among adults [3]. The condition is potentially lethal and has poor survival rates worldwide. The condition is particularly distressing as it occurs acutely in previously 'healthy' individuals and progresses rapidly in spite of all modern treatment.

Most reports on Fulminant hepatic failure have been from the west, and particularly from three countries: the UK, France and also Japan. Recent studies conducted in north and central India found striking differences in the causative spectrum, disease pattern and prognostic factors as compared with the available data from the west $[4,5]$. Present work was thus conducted to study the disease features and derive prognostic indicators that would be relevant to outcome of patients of Fulminant hepatic failure. 


\section{Materials And Methods}

Study Area and Study Period: Study was conducted at department of Medicine of Dr. V.P. Medical College and Hospital. The study duration was from August 2013 to December 2015. (21/2 years). The study was commenced after due approval from the hospital ethics committee.

Study Design: Hospital Based Prospective Observational Study

Sampling Technique \& Sample Size: Consecutive type of non-probability sampling was followed for selection of study subjects. A total of 36 diagnosed cases of Fulminant hepatic failure, fulfilling our inclusion and exclusion criteria were selected for the study after taking informed consent.

\section{Inclusion criteria}

First time diagnosed cases of Fulminant hepatic failure, of age $>18 \mathrm{yrs}$, irrespective of gender, based on following symptoms:

a. Onset of hepatic encephalopathy within 8 weeks of appearance of symptoms of jaundice. And/or;

b. Elevated levels of :

i. Liver function tests: ALT, AST, alkalinephosphatase, GGT, total bilirubin, albumin

ii. Prothrombin time $>30 \mathrm{sec}$

And/or;

c. Viral hepatitis serologies: anti-HAV IgM, HBsAg, anti-HBc IgM, anti-HCV reactive. OR

d. Non-reactive in viral hepatitis serologies.

\section{Exclusion Criteria}

1. Known case of liver cirrhosis presenting with fulminant hepatic failure.

2. Physical trauma to liver.

3. Diagnosed case of Hepatocellular carcinoma presenting with fulminant hepatic failure.

4. Patients not willing to give written informed consent.

\section{Methodology}

The detailed clinical history, complete general, systemic examination, central nervous system examination and investigation findings was noted in a predesigned proforma. The baseline functional status (motor, sensory, autonomous) was assessed and severity of disease was classified using Modified Parsons-Smith scale of hepatic encephalopathy Classification [6]. Patient's progress was observed on the basis of parameters in classification and addition laboratory investigations. Patients was followed till the time of discharge or death, if happens. During hospital stay, patients were monitored for occurrence of complications, if any. The outcome of fulminant hepatic failure was measured in terms of duration of recovery and discharge or death.

\section{Statistical analysis}

The data was analyzed using SPSS ver. 21 using appropriate statistical tests.

\section{Results}

Most of the patients were less than 30 years $(52.8 \%)$ while $22.2 \%$ were above 50 years of age. Female patients were more as compared to males (55.6\% vs $44.4 \%)$. Most common cause of fulminant hepatic failure was HEV (36.1\%) followed by HBV (22.2\%), Indeterminate Hepatitis (22.2\%), AKT induced (8.3\%), Acute fatty liver of Pregnancy (AFLP) (8.3\%) and Auto-immune Hepatitis (2.8\%) (Table 1). Anorexia, nausea, fever, malaise and vomiting were the most common clinical features in the patients. Most of the patients were in encepahalopathy grade III (52.8\%), followed by grade II (25\%) (Table 2). On PA examination, ascites was seen in one third of the patients, while liver percussion > 2 was observed in $44.4 \%$ patients. Raised echo and free fluid was observed in $27.8 \%$ and $33.3 \%$ patients. Sepsis was present in $13.9 \%$ patients and cerebral Oedema was present in $52.8 \%$ patients (table 3). Out of the total 36 patients, 22 patients died $(61.1 \%$ ), while 14 patients (38.9\%) survived (Table 4). Most common cause of death was cerebral edema (72.7\%) while sepsis was the cause in $27.3 \%$ patients. Presence of sepsis, high total billirubin and cerebral oedema were significantly associated with poor outcome $(\mathrm{p}<0.05)$ (Table 5). No significant difference was observed between outcome of patients and varied etiology of hepatic failure ( $p>0.05$ ) (table 6).

\section{Discussion}

Most common cause of fulminant hepatic failure was HEV (36.1\%) followed by HBV (22.2\%). Hepatitis E is an important cause of acute clinical hepatitis in adults throughout Asia [7]. It is also the most common cause of acute viral hepatitis in the adult population in India [8]. In men and non-pregnant women, the disease is usually self-limited and has a case-fatality rate of $<0.1 \%$. However, in pregnant women, particularly 
from certain geographical areas in India, HEV infection is more severe, often leading to fulminant hepatic failure and death in a significant proportion of patients [9].

The disease was first recognized as a distinct clinical entity in the 1980s when sera from persons affected during a large water-borne epidemic of viral hepatitis during 1955-56 in Delhi [8] and another epidemic in Kashmir were found to lack serological markers of acute hepatitis A and B [9]. It is an enterically transmitted disease that spreads through fecal contamination of drinking water. HEV infection, a common cause of waterborne epidemics, is endemic and frequently responsible for acute viral hepatitis in developing countries [10,11]. According to the South-East Asia Regional Office of the World Health Organization (WHO), hepatitis E is widespread in developing countries, accounting for upto $30-70 \%$ of all sporadic cases of acute viral hepatitis $[8,12]$. HEV causes high mortality in pregnant women, $20-30 \%$ as compared to $0.2-1 \%$ in general population $[13,14]$. It has been implicated as an important etiological agent for sporadic fulminant hepatic failure (FHF) in developing countries. The classic epidemiological studies by Viswanathan [10] and recent serological studies by Wong et al. [15] and Khuroo et al. [8] have convincingly demonstrated that HEV is an important cause of non-A non-B viral hepatitis. Our data correspond with the existing epidemiological features of HEV.

In our study, patients with HEV (29.7 years) were relatively younger than the mean age of study subjects (35.2 years). The youngest patient was a child of 12 years age and the oldest patient was a 67 -year-old male. Thus, we found that all age groups were susceptible to hepatitis $\mathrm{E}$ infection, which was comparable to Khuroo et al. [8]. In a study by Tejas et al. the most common age group affected was 21-30 years [16].

Jaundice was present in all patients. Anorexia, nausea, fever, malaise and vomiting were the most common clinical features in the patients of our study. In a study by Tejas et al. most common presenting symptom was jaundice (100\%) followed by nausea/ vomiting (87\%) [16]. In a similar study by Khuroo MS et al. [17] female to male ration was observed as 1.6:1 with mean age of patients as $31.1+/-14.7$ years. Hepatitis E virus was the aetiological cause in 79 (43.9\%) patients, while hepatitis A virus, hepatitis B virus, hepatitis $\mathrm{C}$ virus and non-A, non-E agent/'s could be incriminated in four (2.1\%), 25 (13.9\%), $13(7.2 \%)$ and $56(31.1 \%)$ patients respectively.

A study was done by Jaiswal $\mathrm{AB}$ et al. [18] to establish the aetiology and prognostic factors of Fulminant Hepatic failure (FHF) in central India. Hepatitis E virus (HEV) and hepatitis B virus (HBV) were aetiological agents amongst $41 \%$ and $37 \%$ patients with FHF respectively. Mixed infection among such cases even though observed was infrequent and $15 \%(n=14)$ of FHF did not have any serological markers. They were presumed to be due to non A-E viral infection. Thirty-one (33\%) of the FHF patients were pregnant and 29 (94\%) of them were due to HEV. In present study only $8.8 \%$ females were found to be pregnanat.

In present study, out of the total 36 patients in present study, 22 patients died $(61.1 \%)$, while 14 patients (38.9\%) survived. Most common cause of death was cerebral edema (72.7\%) while sepsis was the cause in $27.3 \%$ patients. No significant difference was observed between outcome of patients and varied etiology of hepatic failure ( $p>0.05)$. Presence of cerebral oedema was significantly associated with poor outcome $(\mathrm{p}<0.05)$. Total billirubin was significantly higher in patients who died compared to survived patients (14.98 vs 11.04 $\mathrm{mg} \% ; \mathrm{p}<0.05)$. The static prognostic risk factors noted in the study by Jaiswal et al. [18] were age above 40 years, presence of identifiable viral aetiology (A to E), alcoholic status in males and pregnancy particularly in the third trimester or postpartum state. Among the dynamic factors, bilirubin level above $20 \mathrm{mg} / \mathrm{dl}$ and prothrombin time over 20 seconds appeared to be the risk factors. In a study by Acharya SK et al. [19] approximately one-third of AHF patients survive with aggressive conservative therapy, whereas two-thirds $(65.6 \%)$ of deaths occur within $72 \mathrm{~h}$ of hospitalization. Cerebral oedema and sepsis are the major fatal complications observed. In a similar study by Kuroo et al. [17] mortality rate was observed as $72.8 \%$ and early predictors of a poor outcome are non-E aetiology, prothrombin time $>30 \mathrm{~s}$, grade of coma $>2$ and age $>40$ years. In a study of early indicators of prognosis in fulminant Hepatic failure by Radha KD et al. [20] mortality rate was $63.9 \%$. Multivariate logistic regression identified 6 independent CPI of adverse outcome on admission: age $>50 \mathrm{yr}$, JEI-7 days, grade 3 or 4 encephalopathy, presence of cerebral edema, prothrombin time $>35$ seconds, and creatinine $>1.5 \mathrm{mg} / \mathrm{dL}$.

\section{Conclusion}

Most common cause of fulminant hepatic failure was HEV followed by HBV. The mortality rate with fulminant hepatic failure was high at $61.1 \%$ with most common causes being cerebral oedema and sepsis. Presence of cerebral oedema and high total billirubin levels were significantly associated with poor outcome.

\section{References}

[1]. C Trey, LS Davidson. The management of fulminant hepatic failure. H Popper, F Schaffner (Eds.), Progress in liver diseases, Grune and Stratton, New York (1970), pp. 282-298.

[2]. Ostapowicz G, Fontana RJ, Schiodt FV, Larson A, Davern TJ, Han SH, et al. Results of a prospective study of acute liver failure at 17 tertiary care centers in the United States. Ann Intern Med 2002; 137: 947-954. 
[3]. OPTN/SRTR 2003 Annual report: transplant data 1993-2002. HHS/HRSA/SPB/DOT; UNOS; URREA. Available at http://www.ustransplant.org. Accessed March 2005

[4]. Dhiman RK, Seth AK, Jain S, Chawla YK, Dilawari JB. Prognostic evaluation of early indicators in fulminant hepatic failure by multivariate analysis. Dig Dis Sci 1998; 43: 1311-1316.

[5]. Batra Y, Bhatkal B, Ojha B, Kaur K, Saraya A, Panda SK, Acharya SK. Vaccination against hepatitis A virus may not be required for schoolchildren in northern India: results of a seroepidemiological survey. Bull World Health Organ 2002; 80: 728-31.

[6]. Ross BD, Jacobson S, Villamil F, Korula J, Kreis R, Ernst T, Shonk T, Moats RA. Subclinical hepatic encephalopathy: proton MR spectroscopic abnormalities. Radiology. 1994 Nov;193(2):457-63.

[7]. Purcell RH, Emerson SU. Hepatitis E: an emerging awareness of an old disease. J Hepatol 2008;48(3):494-503.

[8]. Khuroo MS, Rustgi VK, Dawson GJ, Mushahwar IK, Yattoo GN, Kamili S, et al. Spectrum of hepatitis E virus infection in India. J Med Virol 1994;43(3):281-6.

[9]. Navaneethan U, Al Mohajer M, Shata MT. Hepatitis E and pregnancy: understanding the pathogenesis. Liver Int 2008;28(9):11909.

[10]. Viswanathan R. Infectious hepatitis in Delhi (1955-56): A critical study: Epidemiology. Indian J Med Res 1957;45: 1-30.

[11]. Goumba CM, Yandoko-Nakouné ER, Komas NP. A fatal case of acute hepatitis E among pregnant women, Central African Republic. BMC Res Notes 2010;3:103.

[12]. Chandra NS, Sharma A, Rai RR, Malhotra B. Contribution of hepatitis E virus in acute sporadic hepatitis in north western India. Indian J Med Res 2012;136(3):477-82.

[13]. Patra S, Kumar A, Trivedi SS, Puri M, Sarin SK. Maternal and fetal outcomes in pregnant women with acute hepatitis E virus infection. Ann Intern Med 2007;147(1): 28-33.

[14]. Aggarwal R, Krawczynski K. Hepatitis E: an overview and recent advances in clinical and laboratory research. J Gastroenterol Hepatol 2000;15(1):9-20.

[15]. Wong DC, Purcell RH, Sreenivasan MA, Prasad SR, Pavri KM. Epidemic and endemic hepatitis in India: evidence for a non-A, non-B hepatitis virus aetiology. Lancet 1980;2(8200):876-9.

[16]. MODI, TEJAS N., et al. "A Study of Clinical Profile and Outcome in Acute Viral Hepatitis E." Indian Journal of Clinical Practice 23.10 (2013).

[17]. Khuroo, M. S., and S. Kamili. "Aetiology and prognostic factors in acute liver failure in India." Journal of viral hepatitis 10.3 (2003): 224-231

[18]. Jaiswal, S. B., et al. "Aetiology and prognostic factors in hepatic failure in central India." Tropical gastroenterology: official journal of the Digestive Diseases Foundation 17.4 (1995): 217-220.

[19]. Acharya, Subrat K., et al. "Acute hepatic failure in India: a perspective from the East." Journal of gastroenterology and hepatology 15.5 (2000): 473-479.

[20]. Dhiman, Radha K., et al. "Early indicators of prognosis in fulminant hepatic failure: An assessment of the Model for End- Stage Liver Disease (MELD) and King's College Hospital Criteria." Liver transplantation 13.6 (2007): 814-821.

\section{TABLES}

Table 1. Distribution of patients as per etiology of Fulminant Hematic Failure

\begin{tabular}{|l|c|c|}
\hline Etiology & $\mathbf{N}$ & \% \\
\hline HEV & 13 & $36.1 \%$ \\
\hline HBV & 8 & $22.2 \%$ \\
\hline Indeterminate & 8 & $22.2 \%$ \\
\hline AKT Induced & 3 & $8.3 \%$ \\
\hline Acute fatty Liver of Pregnancy & 3 & $8.3 \%$ \\
\hline Auto-immune Hepatitis & 1 & $2.8 \%$ \\
\hline Total & 36 & $100.0 \%$ \\
\hline
\end{tabular}

Table 2. Distribution of patients as per presenting symptoms

\begin{tabular}{|l|c|c|}
\hline Presenting Symptoms & $\mathbf{N}$ & $\mathbf{\%}$ \\
\hline Fever & 17 & $47.2 \%$ \\
\hline Vomiting & 10 & $27.8 \%$ \\
\hline Pain In Abdomen & 9 & $25.0 \%$ \\
\hline Malaise & 11 & $30.6 \%$ \\
\hline Anorexia & 21 & $58.3 \%$ \\
\hline Nausea & 20 & $55.6 \%$ \\
\hline None & 6 & $16.7 \%$ \\
\hline
\end{tabular}

Table 3. Distribution of patients as per Encephalopathy Grade

\begin{tabular}{|l|c|c|}
\hline Encephalopathy Grade & $\mathbf{N}$ & $\mathbf{\%}$ \\
\hline I & 4 & $11.1 \%$ \\
\hline II & 9 & $25.0 \%$ \\
\hline III & 19 & $52.8 \%$ \\
\hline IV & 4 & $11.1 \%$ \\
\hline Total & 36 & $100.0 \%$ \\
\hline
\end{tabular}

Table 4. Distribution of patients as per Outcome

\begin{tabular}{|l|c|c|}
\hline Outcome & N & \% \\
\hline Death & 22 & $61.1 \%$ \\
\hline Survived & 14 & $38.9 \%$ \\
\hline Total & 36 & $100.0 \%$ \\
\hline
\end{tabular}


Table 5a and 5b. Association of various parameters with outcome in patients of Fulminant Hepatitis

\begin{tabular}{|l|c|c|c|c|}
\hline \multirow{2}{*}{ Variables } & \multicolumn{2}{|c|}{ Outcome } & \multirow{2}{*}{ Total } & p- value \\
\cline { 2 - 3 } & Died (n-22) & Survived (n-14) & & \\
\cline { 2 - 4 } & 5 & 0 & 5 & \multirow{0}{*}{$\mathbf{0 5 4}$} \\
\hline \multirow{2}{*}{ Cerebras } & $100.0 \%$ & $0.0 \%$ & $100.0 \%$ & \\
\cline { 2 - 4 } & 15 & 4 & $100.0 \%$ & $\mathbf{0 . 0 2}$ \\
\hline
\end{tabular}

\begin{tabular}{|c|c|c|c|c|c|}
\hline Variables & Outcome & $\mathbf{N}$ & Mean & SD & p-value \\
\hline \multirow[t]{2}{*}{ Age } & Alive & 14 & 30.86 & 10.95 & \multirow[t]{2}{*}{0.12} \\
\hline & Died & 22 & 37.91 & 13.93 & \\
\hline \multirow[t]{2}{*}{ Total bilirubin } & Alive & 14 & 11.04 & 4.39 & \multirow[t]{2}{*}{0.009} \\
\hline & Died & 22 & 14.98 & 3.96 & \\
\hline \multirow[t]{2}{*}{ SGPT } & Alive & 14 & 411.57 & 294.76 & \multirow[t]{2}{*}{0.36} \\
\hline & Died & 22 & 533.55 & 435.63 & \\
\hline \multirow[t]{2}{*}{ SGOT } & Alive & 14 & 490.29 & 339.61 & \multirow[t]{2}{*}{0.43} \\
\hline & Died & 22 & 617.55 & 523.64 & \\
\hline \multirow[t]{2}{*}{$\mathbf{A P}$} & Alive & 14 & 237.07 & 185.03 & \multirow[t]{2}{*}{0.54} \\
\hline & Died & 22 & 321.09 & 482.13 & \\
\hline \multirow[t]{2}{*}{ PT } & Alive & 14 & 32.21 & 13.43 & \multirow[t]{2}{*}{0.28} \\
\hline & Died & 22 & 36.59 & 10.40 & \\
\hline \multirow[t]{2}{*}{ BUN } & Alive & 14 & 37.86 & 10.38 & \multirow[t]{2}{*}{0.69} \\
\hline & Died & 22 & 39.68 & 14.79 & \\
\hline \multirow[t]{2}{*}{ Creatinine } & Alive & 14 & 1.65 & 1.16 & \multirow[t]{2}{*}{0.47} \\
\hline & Died & 22 & 1.41 & 0.83 & \\
\hline \multirow[t]{2}{*}{ Hospital stay } & Alive & 14 & 15.00 & 5.38 & \multirow[t]{2}{*}{$<0.001$} \\
\hline & Died & 22 & 7.73 & 3.52 & \\
\hline
\end{tabular}

Table 6. Association of various etiologies with outcome in patients of fulminant hepatitis

\begin{tabular}{|l|c|c|c|}
\hline \multirow{2}{*}{ Etiology } & Oied & Survived & Total \\
\cline { 2 - 4 } & 1 & 2 & 3 \\
\hline AFLP & 0 & 1 & 1 \\
\hline AIH & 2 & 1 & 3 \\
\hline AKT & 4 & 4 & 8 \\
\hline HBV & 7 & 6 & 13 \\
\hline HEV & 8 & 0 & 8 \\
\hline Indeterminate & 22 & 14 & 36 \\
\hline Total & \multicolumn{2}{|}{ p- value: $\mathbf{0 . 1 3 7}$} \\
\hline
\end{tabular}

